\title{
FOOD PROCESSING IN VIETNAM: WHERE IS THE POTENTIAL FOR HIGH VALUE EXPORT?
}

\author{
Trung Quang Dinh ${ }^{1}$, Hilmar Pór Hilmarsson ${ }^{2}$ \\ University of Akureyri (Iceland)
}

\begin{abstract}
Vietnam is an emerging market country in South East Asia. Like many countries in the region Vietnam hasadopted a strategy of export lead growth. Recently Vietnam became a lower middle income country but its goal eventually is to reach high income status. Vietnam is a large food producer and exporter. To reach a higher income level Vietnam needs to increase the value added of its products and export more to high income countries. Is it feasible for producers of advanced food processing solutions, including from Europe, to market their products in Vietnam? This article analyses and assesses the seafood and livestock markets. The conclusions show that there are real opportunities for advanced processing solution providers to sell their products in both fisheries and livestock sectors. Growth potential for these providers in the short run seem to be in fisheries sector, while the medium or long term potential, seems to be in the livestock sector.

KEYWORDS: agriculture production and export, food processing, seafood, livestock production, market entry mode, Vietnam.
\end{abstract}

JEL CODES: M31, N7, Q1

\section{Introduction}

Vietnam is an emerging market economy in South East Asia. Like many countries in the region it has adopted a strategy of export lead growth. Recently Vietnam became a lowermiddle income country but its goal eventually to reach high income status.

Vietnam remains an agriculture based economyin which seafood and livestock are among the main sectors for exportand agricultural production growth. The fisheries and aquaculture sectors remain significant contributors to the economy. Total export value of these segments was USD 6 billion in 2011 a 20 percent increase as compared to that of 2010 (SeafoodSource, 2011, p. n.p). The fisheries processing industry in Vietnam is getting more focused and modernized as fisheries products are exported to high income markets such as North-America, Europe, Japan and Australia. These are high income markets paying high prices if strict quality standards are met. Engaging in those markets can increase the total value of Vietnams' fishery exports substantially.

Besides that, livestock sector in Vietnam is well-known for the pork and poultry production. Vietnam ranks the $7^{\text {th }}$ of pork production alone in the world in 2008 (FAO, 2008c). Livestock production of Vietnam reached more than 3.4 million tons in 2008 and it is estimated to continue growing with a fast pace when small and large commercial farms are projected to increase more than 300 percent in 2020 (World Bank, 2009). However the processing industry in livestock sector is still limited due to the traditional purchasing

1 Trung Quang Dinh - M.Sc. in International Business, University of Akureyri, School of Business and Science, Iceland E-mail: quangtrung38@gmail.com

Mobile: +84912933915

2 Hilmar Pór Hilmarsson - professor, University of Akureyri, School of Business and Science, Iceland

E-mail: hilmar@unak.is

Mobile: +3548498380 
characteristics of Vietnamese people. Buying fresh meat after slaughtering from wet market is still practiced by 86 percent of Vietnamese people. Vietnamese people do not have habit buying processed food from supermarkets, convenient store etc. However, this habit is gradually changing and it was estimated that distribution channels like supermarket, hypermarkets, departments store rose 20 percent in the period of 2007-2012 and it is likely to continue rising at the same rate in the next coming years (GAIN, 2008). This will encourage further processing for livestock products e.g. steaks, packaged meat, canned food, sausages etc. when they are distributed in these channels.

The aim of this article is to explore the market potential and feasible market entry and expansion modes for international companies who wish to provide advanced solutions for the food processing industry in Vietnam. The article focuses preliminarily on the fisheries and livestock industries. The article is structured as follows: the first part is introduction section, including discussion about the methodology used. This is followed with a detailed discussion about market potential and market analysis in both the livestock and fisheries sectors. Finally are conclusions and recommendations.

The methodology used for this research was an online survey. After assessing the market potential the authors decided to focus on fisheries sector since this sector signals substantial opportunities for advanced solutions and equipment manufacturers to immediately provide their services and products to this market segment. The survey aimed to understand better the market niche, market behavior and targeted to those companies who financially can afford to import advanced food processing solutions and equipment. A set of questionnaires were sent to a group of top 22 shrimp and catfish processors. These companies were selected based on their export value. The size of these processors ranges from US\$ 30 million to US\$ 126 million (catfish) and US\$ 50 million to US\$ 257 million (shrimp) export value in 2010 (VASEP, 2010).

Secondary data for this research was obtained through various documents e.g. research reports, company annual reports, books, and peer reviewed articles. Secondary data was collected from both internal and external sources. Internal company sources provide information to betterunderstand the selected processors regarding their characteristics, production capabilities, and their operations etc. This data include annual reports from relevant departments in the companies e.g. accounting department, exporting department, brochures and product catalogues. External sources for secondary data in this research are, for example, research reports in related fields i.e. fisheries sector, food processing industry and these documents were collected from e.g. FAO, World Bank and VASEP etc.

\section{Market potential and challenges for the livestock sector} (pork, poultry, and red meat)

The livestock industry is very important for the Vietnamese rural area economy. It accounts for 27 percent of agriculture's contribution to national GDP, about 6 percent of total GDP (World Bank, 2009, p. 1). However, livestock production is fragmented and mainly conducted by small-scale households. There are about 11 million household producers who are small-holders owning from 1-20 pigs and/ or 1-200 poultries, more than 110 thousand farms are small-scale commercial farms and about 6 thousand farms are large-scale commercial. These small-scale households are producing 65 percent of the whole white meat (poultry and pork) in Vietnam in 2008 (see table 1). For poor households, livestock is a major source of food and means to save and accumulate capital. Livestock can also provide draught power (bio-gas), transport (buffalo, cow) organic fertilizer and ready source of household cash. Obviously livestock production plays an important role in Vietnam's agriculture sector which generates jobs and income for 70 percent of the whole population. However, according to World Bank (2009) numbers of small holders are projected to decrease by 18 percent in 2020 and small and large-scale commercial farms are estimated to increase 308 percent and 350 percent respectively (see table 1). 
Table 1. Farm size and production distribution

\begin{tabular}{|c|c|c|c|}
\hline & 2008 & 2020 & $\begin{array}{l}\text { Projected Growth } \\
\text { (\%) }\end{array}$ \\
\hline \multicolumn{4}{|c|}{$\begin{array}{l}\text { A. Structure of poultry and pig production } \\
\text { (number of farms) }\end{array}$} \\
\hline Smallholders & $11,000,000$ & $9,000,000$ & $-18 \%$ \\
\hline Small-scale Commercial Farms & 110,368 & 450,000 & $308 \%$ \\
\hline Large-scale Commercial Farms & 5,800 & 26,100 & $350 \%$ \\
\hline \multicolumn{4}{|c|}{ B. Domestic meat production and Imports (000mt) } \\
\hline Pork and poultry meat & 3,190 & 5,140 & $61 \%$ \\
\hline Red meat & 300 & 400 & $33 \%$ \\
\hline Net meat imports $(\mathrm{mt})$ & 120 & 280 & $133 \%$ \\
\hline Total meat & 3,610 & 5,820 & $61 \%$ \\
\hline \multicolumn{4}{|c|}{$\begin{array}{l}\text { C. Share of pork and poultry meat production } \\
(000 \mathrm{mt})\end{array}$} \\
\hline Smallholders & 2,070 & 1,902 & $-8 \%$ \\
\hline Small-scale Commercial Farms & 800 & 2,467 & $208 \%$ \\
\hline Large-scale Commercial Farms & 320 & 771 & $141 \%$ \\
\hline Total domestic meat production & 3,190 & 5,140 & $61 \%$ \\
\hline Definitions (number of animals/farm) & Pigs & Poultry & \\
\hline Smallholders & $1-20$ & $1-200$ & \\
\hline Small-scale Commercial Farms & $21-500$ & $201-2,000$ & \\
\hline Large-scale Commercial Farms & $501-15,000$ & $2,001-200,000$ & \\
\hline
\end{tabular}

Source: World Bank, 2009

Most small-scale producers are located in Red River Delta areas and its vicinity provinces (Northern of Vietnam: Hanoi, Hai Phong, Hai Duong, Thai Binh) and Mekong Delta River (Southern of Vietnam: Ho Chi Minh City provinces, Long An, Dong Nai, Lam Dong) which accounts for 76 percent (see table 2) of the whole national livestock production (World Bank, 2009).

Table 2. Proportion of pork and poultry production in Vietnam

\begin{tabular}{lccc}
\hline \multicolumn{1}{c}{ Administrative Region } & $\begin{array}{c}\text { Pig and Poultry Meat } \\
\text { Production }\end{array}$ & $\begin{array}{c}\text { Poultry Smallholder } \\
\text { Producers }\end{array}$ & $\begin{array}{c}\text { Pig Smallholder } \\
\text { Producers }\end{array}$ \\
\cline { 1 - 3 } $\begin{array}{l}\text { Red River Delta } \\
\text { South East }\end{array}$ & $76 \%$ & $72 \%$ & $72 \%$ \\
$\begin{array}{l}\text { Mekong Delta } \\
\text { North Central }\end{array}$ & $19 \%$ & $21 \%$ & $16 \%$ \\
$\begin{array}{l}\text { North East } \\
\text { South Central }\end{array}$ & $5 \%$ & $8 \%$ & $6 \%$ \\
\hline $\begin{array}{l}\text { North West } \\
\text { Central Highlands }\end{array}$ & & & \\
\hline
\end{tabular}

Source: World Bank, 2009

\subsection{Livestock Production}

Livestock production in Vietnam includes pig, chicken, beef, buffalo and small number of goats. The largest share of livestock products are pork 79.4 percent, poultry 12 percent and red meat 8.6 percent (see 
figure 1). Pork is the main nutrition and most consumed meat in Vietnam comparing with chicken or other red meat. In recent years, i.e. from 2006 to 2009, production of pork has been increasing on average of 4.5 percent year on year (FAO, 2009b), while poultry also grew rapidly and increased from 358,8 metric tons in 2007 to 448,2 metric tons in $2008^{3}$, a 25 percent increase. However, growth of poultry production did slowdown in 2009 with 518.3 metric tons and increased only 15.6 percent compared with previous year (FAO, 2009a).

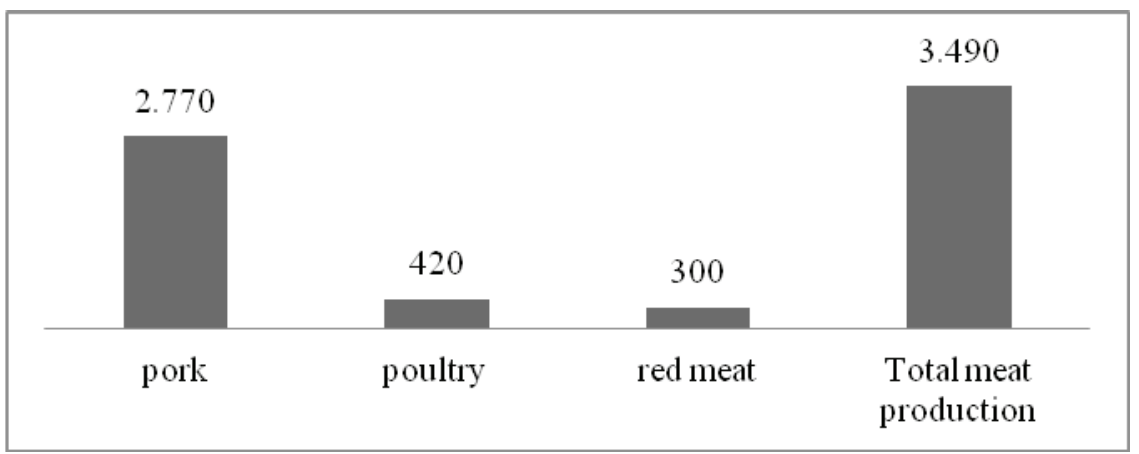

Figure 1. Vietnam's domestic meat production in $2008(000 \mathrm{mt})$

Source: WorldBank, 2009

\subsubsection{Pork}

Vietnam ranks $7^{\text {th }}$ of largest pork producers in the world, the top four countries in pork production is China, US, Germany and Spain in 2008 (FAO, 2008c). The recent increase in livestock production has been driven by rising domestic demand, particularly in urban areas where per capita incomes have risen fastest and the demand for a more varied diet has increased the demand for livestock products. Between 2000 and 2005 , consumption of livestock products increased by 7.8 percent per annum (World Bank, 2009). And from 2006 to 2009 Vietnam's pork production has been increasing 4.5 percent on average year on year rising from 2.5 million tons to 2.9 million tons. The main pork export from Vietnam is suckling pigs. This segment in the past has been exported to several neighboring countries, but disease concerns have recently restricted exports, only to the biggest market, Hong Kong. In 2008 Vietnam exported 9.113 thousand tons of pig meat (FAO, 2008a); however, Vietnam still needed to import 22.644 thousand tons of pig meat the same year mostly from US 27 percent, Canada 23 percent, Hong Kong and China 23 percent (AAFC, 2010).

\subsubsection{Poultry}

After pork, poultry is the second most important meat for the Vietnamese people. The production of poultry ranks the second in livestock industry about 12 percent (see figure 1). Poultry production is mostly practiced in Red River Delta (North of Vietnam) with 26 percent of total production, followed by Mekong River Delta (South of Vietnam) with 20 percent, the northeast with 16 percent and the northeast of the Southern Vietnam with 10 percent. These four regions account for 72 percent of the country's poultry production. Ducks are also produced in Mekong River Delta accounting for 48.3 percent of the poultry production while in Red River Delta it accounts for 23.5 percent (FAO, 2008b). Like pork production, poultry is mainly owned by small-scale households. 92 percent of poultry producers are small-holders. Among main constraints faced by these small-scale households are lack of knowledge and access to production innovation due to weak capital investment, limited ability in disease prevention and control. Farmers are raising poultry based on traditional customs and experience rather than learning new husbandry practices and knowledge. Therefore Vietnam's poultry production remains limited and inefficient.

3 There is a difference in poultry production in 2008 between FAO (448.2 thousand metric tons) and World Bank 2009 (420 thousand metric tons). 
Poultry production increased rapidly between 2007 and 2008, i.e. by 25 percent from more than 358.8 thousand metric tons to 448.2 thousand tons. This growth slowed down in 2009 with 15 percent increase compared with previous year or 518 thousand tons in volume (FAO, 2009a). Production capacity in poultry is far less than that of pork (see figure 2) and poultry sector is not able to supply sufficiently for local consumption. And thus Vietnam had to import 222.636 thousand tons of frozen chicken part and its offal in 2008 accounted 34 percent of total meat and poultry import volume. The key supply countries were USA (24 percent), Turkey (15 percent) and Hong Kong (14 percent) (AAFC, 2010).

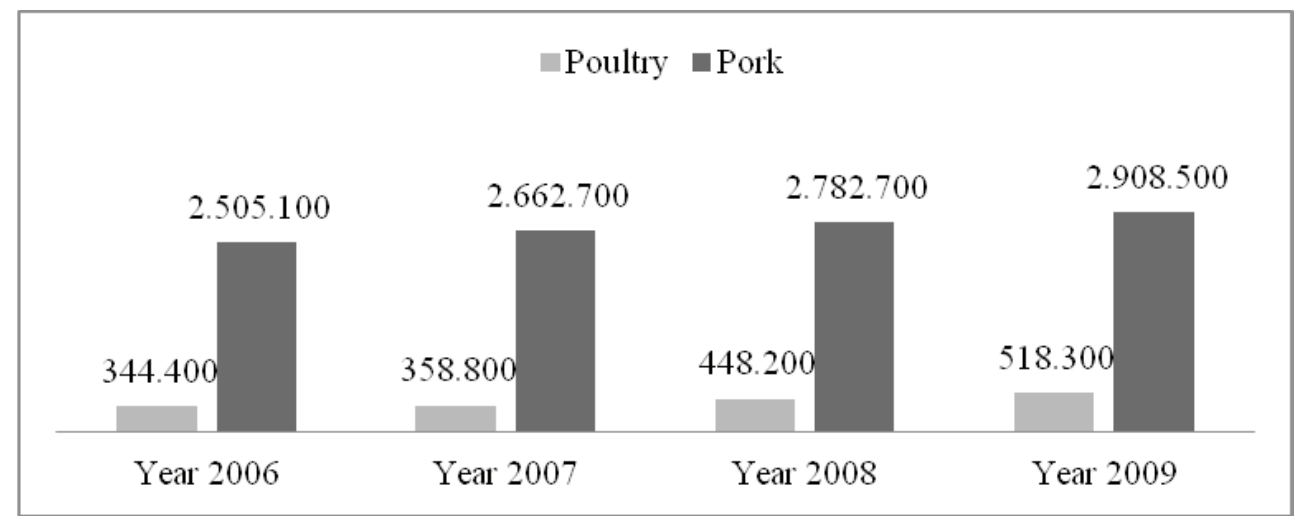

Figure 2. Poultry and pork production from 2006 to 2009 (mt $)^{4}$

Source: FAO, 2009a, b

\subsubsection{Red meat}

Cows and buffalos in Vietnam are mainly raised to work in rural areas. Vietnamese farmers in many communities are still using cows and buffalos as the main animals to work on their farms and fields rather than technological equipment or machines. Cows and buffalos are also used as a means of transportation in these areas. In addition to that, these big animals are a cash source and "fixed" assets in households (Dinh, 2009). Majority number of cows in Vietnam is raised for diary production and only small number of cows and buffalos are raised for meat production purpose due to intensive capital investment and long time to return on investment. There are some commercial farms for meat production but these farms also remain a minority. In the livestock production, share of red meat in Vietnam is very small 8.6 percent of total production. Red meat also accounts for only 9.5 percent of total meat consumption of the Vietnamese people and it has been estimated that Vietnam had to import $0.3 \mathrm{~kg}$ red meat per capita in 2008 (Vietnamese population was about 86 million) to fulfill local consumption demand (World Bank, 2009, p. 20). As a result, Vietnam imported 139.320 thousand tons of beef in 2008, of which 98.4 percent was frozen beef from India and USA; the rest of 1.6 percent is fresh/ chilled beef from USA, Australia and New Zealand.

\subsection{Livestock processing and distribution}

So far livestock processing in Vietnam has not been practiced in an advanced way with technology or comprehensive equipment. For the livestock sector, the term "processing" is understood as "slaughtering" because slaughtering is the main activity done after livestock is taken from the farms and before it is sold at the wet market ${ }^{5}$. The vast majority of livestock slaughtering in Vietnam is carried out under unhygienic

4 There is a difference in poultry production in 2008 between FAO (448.2 thousand metric tons) and World Bank 2009 (420 thousand metric tons).

5 The main characteristics of the market have traditionally been associated with a place that sells live animals out in the open. The collection may include poultry, fish, reptiles, and pigs. In Vietnam nowadays, wet market is usually 
backyard conditions by households who specialized in this job. The slaughtering of livestock takes places at floor level where carcass contamination is heavy. Small privately owned or commune-owned slaughterhouses process from 5 to 50 pigs and a dozen of poultry per day. They buy pigs or poultry almost entirely directly from household producers or via middlepersons and after slaughtering this meat is sold exclusively to the wet market. Large commercial public owned plants or privately owned slaughtering plants buy from commercial farms and sell mainly to supermarket and restaurants or hotels. Although ante-mortemmeat inspection is carried out, carcass condemnations are few and almost no post-mortemexamination or sampling takes place. Meat inspection does not always take place and is best described as cursory (World Bank, 2009). Yet, this fresh meat is sold right after slaughtering at wet markets without any further processing like cutting, slicing, portioning, forming nor packaging.

As mentioned above, most of the meat after slaughtering is distributed to wet markets. Even though urbanization is currently booming in Vietnam which encourages the establishment of supermarkets, hypermarkets and many other convenient department stores, buying fresh food including meat, fish, vegetable at wet markets is still daily practiced by 86 percent of Vietnam's consumers. There are hundreds of thousand wet markets across the country that sell meat and fish to the consumers. Consumers can find all daily basic food items and other products for households in these markets. However, it was estimated that there were 14 percent of consumers buying food from supermarket, hypermarkets or department stores like Big C, Metro Cash \& Carry (mainly for wholesalers), Fivimart, Hapromart, etc. in 2007 (GAIN, 2008, p. 5). A combination of strong economic growth, rising income levels, a growing middle class, a sizable young population, and an increase in western lifestyle are causing the rapid growth of modern trade in Vietnam. In the period of 2003-2007, modern trade in Vietnam achieved an average growth of 20 percent and it was expected to continue to grow at this rate for the next five years (GAIN, 2008, p. 5). These supermarkets are estimated to be the main channel of distribution in big cities in Vietnam in the future.

\subsection{Preliminary conclusion for the livestock sector}

Livestock production has been increasing in capacity and seeking to fulfill the domestic consumption demand. The Government's Strategy for the Development of the Livestock Sector ${ }^{6}$ was approved by the Prime Minister in January 2008. It proposed that priority ${ }^{7}$ be given to meeting domestic demand and set meat production targeted of 3.2 million tons in 2010 rising to 5.5 million tons in 2020 (World Bank, 2009). There is a trend for large-scale farms with intensive and organized models to develop (see table 1) and small-scale farms will decrease. This will help the Vietnam's livestock sector to develop in a more industrial way, enhance the food processing industry and enable it to expand to a larger extent. In Vietnam currently, livestock is slaughtered and processed preliminarily and is sold to consumers. Meat in general is not much processed with equipment like cutting, slicing, portioning, packaging nor labeling in Vietnam due to the traditional behavior characteristics of Vietnamese people.

Though, there are some big food processors (both state owned and privately owned) in Vietnam who mainly focus on producing sausages, Chinese sausages, spring rolls, canned meat. Most of these products are served for local market. Given limited data obtained from these processors (as most of them are state-owned enterprises and sensitive in releasing information publicly). Currently, target consumers of these processors

an open air market where buyers can buy all kind of daily basic food. In many rural areas, farmers directly sell their products like fish, poultry, vegetables that they produce or catch on their farms or fields.

6 Decision No. 10/2008/QD-TTg dated January 16, 2008 of the Prime Minister approving the strategy on animal breeding development up to 2020http://luatvietnam.vn/default.aspx?tabid=651\&id=38369FE9-5FC4-411D-9B8F8F2AFE1A6B1 A\&rurl=\%2fVL \%2f662\%2fQuyet-dinh-102008QDTTg-cua-Thu-tuong-Chinh-phu-ve-viec-pheduyet-Chien-luoc-phat-trien-chan-nuoi-den\%2f38369FE9-5FC4-411D-9B8F-8F2AFE1A6B1A\%2fdefault.aspx.

7 Priority here includes tax exemption and/or low import tax rate (equipment, machinery). Decision No 394/QDTTg, made by the Prime Minister in 2006 (valid from 2006-2008), was to support enterprises by giving priorities in land use, science and technology knowledge assistance, as well as to support them pay off at least $40 \%$ of interest rate of commercial loans. 
are local markets and it takes time for them to shift to exporting activities where high international standards in terms of hygiene, quality, packaging and labeling are strictly required.

\section{Market potential and challenges for the fisheries sector}

Vietnam, with a coastline of over 3,260 kilometers $(\mathrm{km})$ and more than 3,000 islands and islets scattered offshore, plus up to 2,860 rivers and estuaries, has been geographically endowed with ideal conditions for a thriving fisheries sector. For centuries, the Mekong River Delta in the south and the Red River Delta in the north have been used for wild catch fishing as well as extensive fish farming. The Mekong River Delta, one of the most productive fishery zones, covers an area of about 40,000 square $\mathrm{km}$. In addition, there are about 4,200 square $\mathrm{km}$ of rivers, lakes and other natural bodies of water further inland, which swell to an additional 6,000 square $\mathrm{km}$ during periods of seasonal flooding (FAO, 2005).

The fisheries and aquaculture sectors are significant contributors to the economy of Vietnam. Total export value of those sectors was USD 6 billion in 2011 increased 20 percent compared to that of 2010 (SeafoodSource, 2011, p. n.p). About 50 percent of fish production comes from aquaculture (see figure 5). According to the Royal Embassy of Denmark in Vietnam in 2010, "Vietnamese aquaculture output and value have soared at an annual average growth rate of approximately 20 percent from 2000, exceeding the already high rates of the 1990s. By 2008 Vietnam accounted for almost five percent of world aquaculture output and value, triple that of 1990. Together, two products, Pangasius and the Giant Tiger Shrimp dominate, accounting for about two-thirds of total production and value. Moreover, this species dependence has increased over time. Production is concentrated geographically in the Mekong Delta and in particular the provinces of Dong Thap, An Giang, and Ca Mau. The narrow dependence on two species has enabled the aquaculture sector to specialize, but it has negative implications for economic risk and regional equity" (Royal Embassy of Denmark, 2010, p. 6). Vietnam's fisheries product exports have increased considerable in recent years becoming a major income earner and one of Vietnam's major export commodities. Aquatic products earned USD 3.36 billion in 2006, USD 4.50 billion in 2008 and USD 5.03 billion in 2010. Total export volume for 2010 was 1,353,156 tons, an 11.3 percent increase over 2009. Shrimp and pangasius are by far the most important aquatic exports, accounting for over 41.9 percent and 28.4 percent respectively of total fisheries export earnings in 2010 (VASEP, 2010) ${ }^{8}$. Currently Vietnam exports fisheries products to many countries all over the world but the main markets are: EU 23.5 percent market share (including, Germany, Spain, Holland, Italy and Belgium with main products as pangasius and shrimp), Japan 17.8 percent (shrimp), USA 19.3 percent (shrimp and pangasius). A large share of Vietnamese fisheries products are thus already going to high income economies.

In Vietnam there are around one thousand seafood processors of which about 500 are also exporters recorded by VASEP. Most of the biggest processors are located in the south around Mekong Delta that supplies 58.7 percent of raw material, and is the largest raw material supplier in the country (see figure 4). In spite of a large number of processors operating in the country, exporting and production of fisheries products is conducted (at a large extent) by only top ten key processors who account for 21 percent of total export earnings in 2009. The top ten exporters (including pangasius and shrimp) yielded the value of USD 894.337 million (214.628 thousand tons) in 2009 alone (VASEP, 2009).

8 Vietnam Association of Seafood Exporters and Producers (VASEP) is a non-governmental organization, established on June 12th 1998, based on the principles of volunteer, autonomy and equality. VASEP members include leading Vietnamese seafood producers and exporters and companies providing service to the seafood sector. 


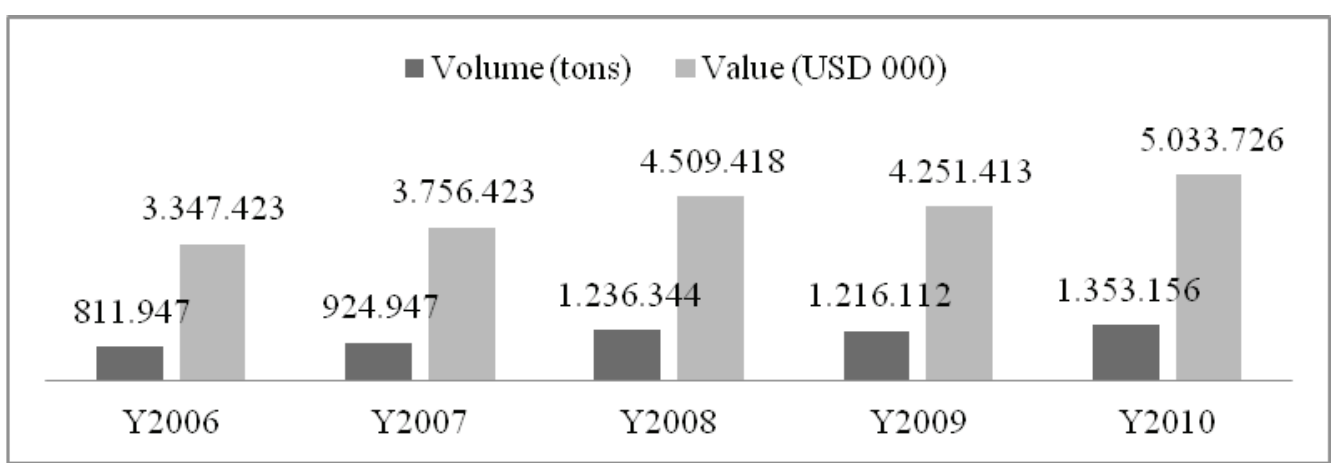

Figure 3. Volume and value of Vietnamese fisheries export (including aquatic products) from 2006 to 2010

Source: VASEP, from 2006 to $2010^{9}$

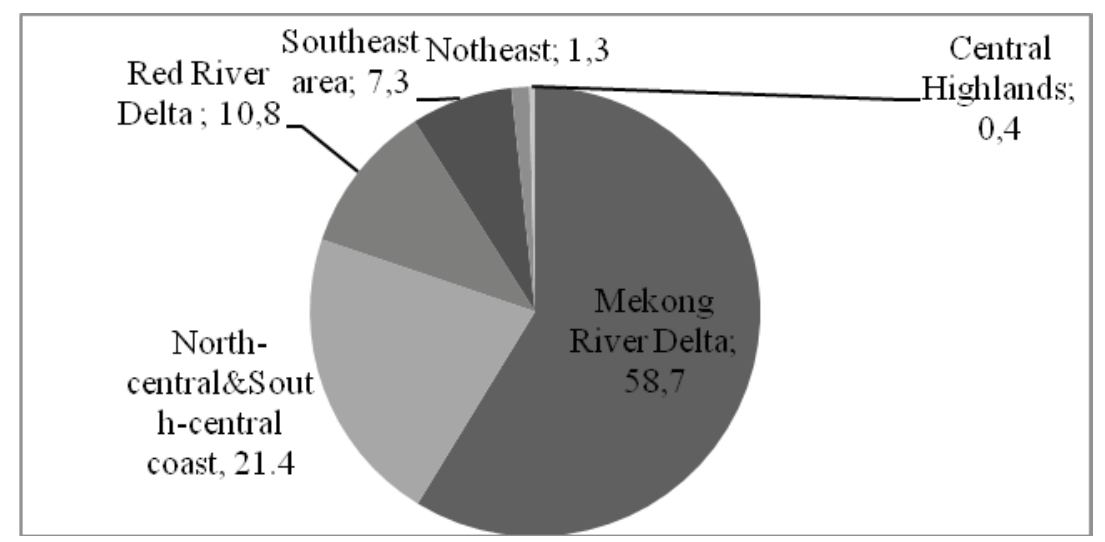

Figure 4. Fisheries raw material supply by region in Vietnam in 2008 (in percent)

Source: Sacombank, 2010

\subsection{Market analysis for the fisheries sector}

As the analysis above has shown the livestock sector in Vietnam is currently in its early stage of modernization and industrialization. This section will thus focus on fisheries sector.

\subsubsection{Buyers' characteristics, fisheries processors}

As mentioned in the overview section of the fisheries industry, shrimp and pangasius are by far the largest fisheries export products, accounting for $41.9 \%$ and $28.4 \%$ respectively of total fisheries export earnings in 2010 (VASEP, 2010). As a result, most of those who are among the largest processors operate in those two products. Obviously targeted customers for advanced solutions and equipment providers are these large processors $^{10}$ as these companies may potentially have financial ability to purchase highly advanced and capital intensive equipment. Moreover, advanced solutions and equipment provided by these companiesis designed to serve large production capacity plants and therefore a processor needs to have large volume of raw material processed per day in order to benefit sufficiently from this equipment.

As mentioned in methodology section, a set of questionnaire were sent to the 22 largest fisheries processors in Vietnam to understand better their key characteristics, production capacity, their need for moderniza-

9 Data of Vietnam's fisheries exports from 2006 to 2010 was sent to the author by VASEP via emails dated July 14 , 2011.

10 Those who are regarded as large processors may produce about 100 tons of raw material per day for pangasius and 50 tons per day for shrimp. 
tion in processing lines and possible relevant constraints. This group of top 22 shrimp and pangasius processors were selected based on their export value. The size of those processors ranges from US\$ 30 million to US\$ 126 million (pangasius) and US\$ 50 million to US\$ 257 million (shrimp) in export value in 2010 (VASEP, 2010). This group is not representative for the whole fisheries processors in the industry and one cannot make any generalizations about the whole industry from the responses provided by those processors. However one may learn something about those few large processors and some of those processors could be among potential customers of advanced solutions and equipment providers.

- The largest processors (who also are the largest exporters) focus solely or mainly on high value fisheries products which in the case of Vietnam are shrimp and pangasius fillet. There are around 500 hundred seafood exporters (out of about one thousand seafood processors in total) who export many fisheries products including shrimp, pangasius, squid, octopus, crab processed in frozen, fresh or chilled from Vietnam. However shrimp and pangasius are the main and high value products. The top ten exporters of these two products were contributing about 21 percent of total export earnings in 2009 (VASEP, 2009, p. n.p).

- Large processors tend to target their products to high income markets/economies such as USA, Europe, Japan and South Korea. 68.3 percent of fisheries products are exported to these three big markets (VASEP, 2010). These markets demand high quality and strict hygienic standards and exporters to these markets have to meet this requirement in terms of quality control, hygienic, packaging and labeling if they want to remain and compete with other international competitors.

- There is a growing trend in expanding aquaculture production among those large processors to lessen dependence on raw materials from wild catching and or from middlemen. The common constraint for fisheries processors in Vietnam in general is lack of raw material due to decrease in unplanned wild capture. This severely affects large processors when they rely too much on this source of raw material. In order to lessen this dependence, in recent years, large processors have set up their own fish/shrimp farms. Many other processors (or even those who already have their own farms) have contract with other farms to purchase raw materials according to their production plan. This practice helps processors become more independent in supply source and helps ensure more stable production. Aquaculture increased rapidly not only in volume but also in value. Aquaculture tonnage of Vietnam soared at an annual growth rate of about 20 percent from 2000 to 2008. Vietnam's aquaculture seafood volume and value accounted for almost 5 percent of world aquaculture output (Royal Embassy of Denmark, 2010, p. 25). The leaders in this aquaculture trend e.g. Vinh Hoan company can self-supply 50 percent raw material for production a year, Hung Vuong 50 percent, Bianfishco 40 percent (these are pangasius processors); and Minh Phu 10 percent, Utxico 40 percent (these are processors in shrimp) (Sacombank, 2010, p. 11). They have their own farms and foodstuff factories (also see figure 5 for aquaculture components and growth).

- Many large processors are fully aware of the importance of modernizing their processing equipment to increase quality, hygienic standards and value added of their products. Most of the large processors responded that they plan to modernize their processing lines to be more competitive, gain more market share and increase revenue. In recent years large processors have installed new expensive equipment imported from Europe.

- Another important observation is that funding is identified as the main constraint for most processors. Investment in new technology and advanced equipment in food processing lines often requires large capital investments. Harsh international competition challenges exporters to produce their products in line with very good quality standards that result in high value products. However, when it comes to funding the modernization Vietnamese processors appear to face difficulties. Common finding suggest that all of the larger processors can get some loans from State-owned Commercial Banks, the Vietnam Bank for Agriculture and Rural Development (VNBARD), some International Banks, the Development Assistant Fund (DAF). They also use part of their own company's cash flow. In spite of access to these resources almost all processors address funding as their main constraint. As a result, a more focused research addressing funding constraints and suggesting financing alternatives for both Vietnamese processors and advanced solutions providers are discussed in some detail in Dinh and Hilmarsson (2012a, 2012b, 2012c and 2013). 
- Beside the financial constraints the short term payment for equipment is commonly mentioned by large processors. Most processors claim that they have to pay within 3 to 6 months after the equipment is delivered or fully installed. This short repayment time may affect their cash-flow. Given this short repayment time processors may end up buying only the most important equipment and not invest in large and comprehensive solutions that in the long term could maximize their profits. See more at Dinh and Hilmarsson (2012a, 2012b, $2012 \mathrm{c}$ and 2013).

- The fisheries sector in Vietnam is developing fast and firmly (see figure 3). Production capacity and export value is getting higher and higher (export value increased 18.4 percent in 2010 compared with 2009, VASEP, 2010). The number of processors is also increasing and performance of these processors is getting better thanks to their application of new technology and advanced equipment in processing lines. As a result, from their responses most of these processors are planning to continue modernizing their equipment and seek better solutions that yield more value and reduce manual work. All those who report that they have modernization plans say that this could likely happen within next 2 years and some others within next 3 to 4 years.

- Freezing equipment seems to be a common problem among these processors. 5 out of 13 processors said that they want to modernize their freezing equipment.

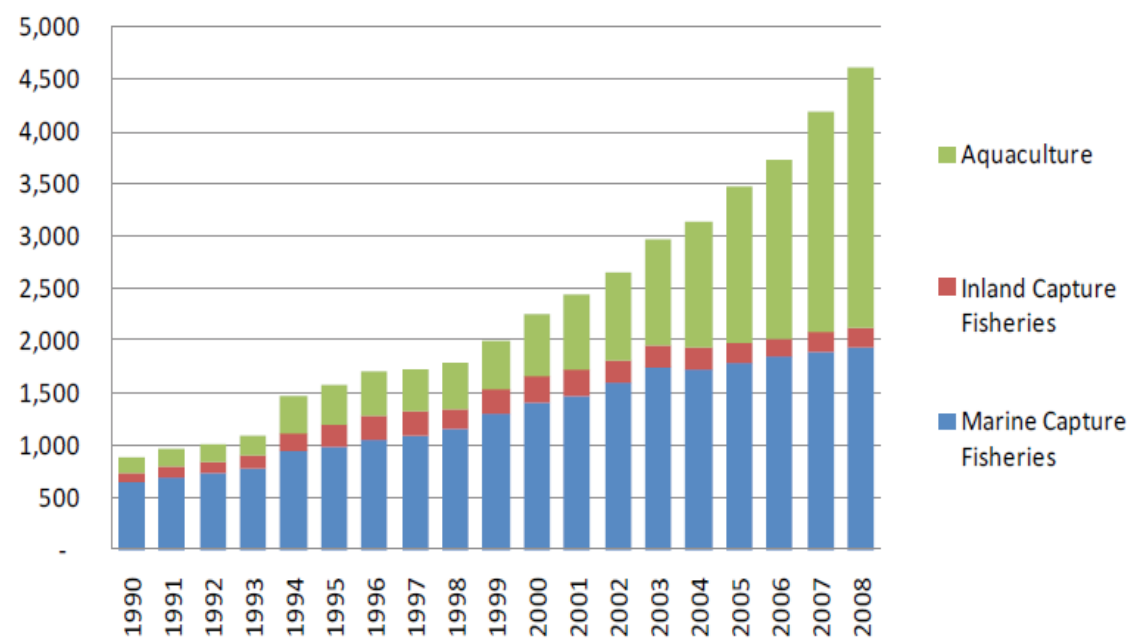

Figure 5. Total fisheries sector production in Vietnam in 2008 (tons)

Source: Royal Embassy of Denmark, 2010

\subsubsection{Market Competitiveness}

The demand for machinery and equipment for the food processing industry is increasing as the Vietnamese Government is creating a more favorable environment for this industry to grow. The economy is being industrialized and both government policy and the intension of many food processors are to move increasingly towards high value products. Many processors in the food industry in Vietnam are therefore taking steps to modernize their equipment to increase their value added. Vietnam is now a low middle income country and given the strong growth rate in recent decades the move from low value to high value products is what necessary to achieve upper middle income status and eventually high income status. Although there is a single party communist government in Vietnam market economic principles have been adopted and the increase in value added must be private sector driven. However, the government can support by introducing policies that are conducive to private sector growth.

Food and beverage processing equipment consists of many different processing categories applied in the food and beverage industry such as: slaughtering, processing, packaging, wrapping, cooking, freezing, forming, filling, conveying and sealing equipment etc. And thus supply of food processing equipment is constantly being enhanced by both local and international manufacturers in Vietnam. This is especially true in 
fisheries sector since this sector needs to meet high international quality and hygienic standards; and also to increase the value of exported products. Demand for livestock processing equipment will also increase in the coming years to meet the various local consumption demands such as diet food, canned meat, sausage, etc.

The demand for machinery and equipment in the food industry in Vietnam is strong and the domestic machinery supply cannot satisfy internal demands due to the poor design and low quality. It should be noted that copycat is one of major problems in this segment as these copycat products do not ensure good quality. Due to low production costs and the targeted consumers (of small scale processing enterprises) most domestic equipment is used by small scale processing enterprises because domestic consumption and the standards required are not as high as those targeted to international markets. Medium and large processing enterprises usually tend to import advanced equipment yet combine with using domestic equipment in some processing lines. Instead of using comprehensive solutions there is a tendency to use piece-meal solutions in Vietnam. Major international suppliers are from Japan, China and Taiwan. Japanese products are known for good quality and durability whereas Taiwanese and Chinese products tend to be chosen for affordability. Other high quality suppliers come from Denmark, Germany, Sweden, France, and Italy (Swiss Business Hub ASEAN, 2006). Vietnam food processing expanded rapidly and experienced an average growth rate of over $10 \%$ annually, in the last few years, according to GAIN 2009 (including dairy products, meats, seafood, fruits and vegetable) (GAIN, 2009). As a result the local and international manufacturers are trying to tailor to food processing industry to meet the demands from food processing enterprises.

Currently in Vietnam, the main equipment providers in food processing industry (in livestock and fisheries sectors) are categorized into three groups: (i) local manufacturers, (ii) international manufacturers from EU, U.S, Japan and South Korea (regarded as high range quality and expensive), and (iii) middle range products imported from other Asian manufacturers like Taiwan, China, and Thailand. The foreign market players have been providing their solutions and equipment in livestock and fisheries production. Their presence in Vietnam is mainly conducted in the forms of representative office, local sales agencies. Most of the advanced foreign players come from Europe, U.S. and Japan.

\subsection{Recommended market segment}

Based on recent secondary data, primary information i.e. responses to a questionnaire from the 22 largest processors and emails exchanged with relevant persons in the industry, the research shows a firm and continuous development in the fisheries and aquaculture sectors and increasing contributions to the economy of Vietnam. The fisheries and aquaculture sectors are targeted to account for 30-35 percent of agriculture, forestry and fisheries by 2020 (in the contribution to GDP of this group); and they were targeted to have a growth rate of 6-7 percent in fisheries production value for the period of 2011 to 2015 (Royal Embassy of Denmark, 2010, p. 16). Vietnam's fisheries and aquatic product exports have increased considerably in recent years becoming a major income earner and one of Vietnam's major export commodities. Fisheries and aquatic products earned USD 3.36 billion in 2006, USD4.50 billion in 2008 and USD5.03 billion in 2010. Total export volume for 2010 was 1,353,156 tons, an 11.3 percent increase over 2009 (VASEP, 2010). In 2011 total export value of the fisheries and aquatic sectors (including aquaculture) was USD 6 billion (SeafoodSource, 2011, p. n.p). The number of fisheries processors is increasing and there are more and more key players who are aware of the importance of modernizing the processing lines to compete in an international context.

However, fisheries production value of Vietnam still remains low. The products for export do not generate much value added, many products are just semi-processed. Nevertheless the main export markets are high income countries and these markets follow very strict regulations on quality control, hygienic standards, packaging and labeling issues. In order to compete successfully and increase export earnings, Vietnamese exporters need to increase their value added. They must modernize their processing equipment to meet strict market demands and this is opportunity for advanced solutions and equipment providers. 
In the meantime, the livestock production industry is also discussed to a certain extent in the article. Total livestock production in 2008 was more than 3.4 million tons including pork, poultry and meat. The production increase is estimated to continue and reach 5.5 million tons in 2020 (World Bank, 2009, p. 21). However, current livestock production is fragmented, 98 percent of total producers are smallholders and yielded only 65 percent of total production while 2 percent of producers are small and large scale commercial farms yielded 35 percent. Though, these small and large commercial farms were projected to increase their production 308 and 350 percent respectively while small-holders reduce their production 18 percent by 2020 (World Bank, 2009, p. 21). Besides that, the livestock processing industry has not been widely practiced because 86 percent of the Vietnamese consumers are still buying food and every kind of essential nutrition from wet markets where fresh meat is sold after slaughtering. Only small amount of meat is processed (sausages, portioned \& packaged meat, canned meat) and distributed in supermarkets. However, such distribution channels like supermarkets, hypermarkets, department stores such as, Big C, Metro Cash \& Carry, Fivimart, Hapromart grow by 20 percent in the period of 2008-2012 (GAIN, 2008, p. 5). This also will encourage further processing for livestock products e.g. steaks, packaged meat, canned food, sausages etc. when they are distributed in these places.

Given the limited data availability this article does not cover and or address all the relevant issues in the fisheries and livestock sectors in Vietnam. However, through this research one can see that the fisheries processing industry is expanding rapidly. In addition to that, exporting fisheries products forces Vietnamese processors to modernize their processing lines and have better quality control systems in order to meet required standards and compete more effectively with international competitors. This fact creates substantial opportunities for advanced processing solution providers to provide its services and products to this market segment immediately. At the same time, those whoalso provide processing solutions for livestock sector can initiate plans to tap into this segment as their medium and long term strategy.

\section{Conclusions}

Vietnam is an emerging market country in South East Asia. Like many countries in the region Vietnam has adopted a strategy of export lead growth. Recently Vietnam became a lower middle income country but its goal eventually is to reach high income status.

Vietnam is a large food producer and exporter. To reach a higher income level its needs to increase the value added of its products and export more to high income countries. Through the market research done in this article one can see that Vietnam food processing industry is booming and has a strong growth potential.

Within the food processing industry of Vietnam the fisheries sector is regarded as vanguard sector in modernizing and industrializing the processing lines and equipment. This is due to the harsh competition that Vietnamese fisheries processors are faced with when they export to high income international markets.

The livestock sector still remains less innovative and employs less sophisticated processing lines. This is because the majority of the production in this segment is served for the local consumption. However, the fast pace of economic development in Vietnam and the urbanization in the main cities and nationwide will force the growth of hygienic specialized distribution channels. These channels are, for instance, hypermarkets, departments store, supermarkets like Big C, Metro Cash \& Carry, Fivimart, Hapromart which were estimated to grow 20 percent in the period of 2008-2012 and this growth continues.

Processed and further processed food including livestock products e.g. packaged meat, canned meat, and sausages etc., will be required, and become increasingly dominant in these channels. This is an opportunity for advanced processing solution providers to expand operation and increase salve volume in both fisheries and livestock sectors.

In summary, the short run growth potential for these providers seem to be in fisheries sector while the medium or long term potential seem to be in livestock sector. Those companies who wish to enter or expand their business in food processing industry in Vietnam should also bear in mind that funding is identified as 
main constraint faced by Vietnamese processors. This issue is discussed in detail and alternatives to help solve this problem are also suggested in other articles written by the authors and reference is made to in this article.

\section{References}

AAFC. (2010). Statistics and Market Information. Retrieved September 10, 2013, from Agriculture and Agri-Food Canada. Website: http://www.ats-sea.agr.gc.ca/ase/5682-eng.htm

Dinh, T. Q., Hilmarsson, H. P. (2012a). What are the Economics Justifications for the Existence of Export Credit Agencies and How Can They Facilitate Cross Border Trade to Emerging Market Economies? Journal of Regional Formation and Development Studies, vol. 6, p. 15-25.

Dinh, T. Q., Hilmarsson, H. P. (2012b). Private Sector Export to Emerging Market Economies During Times of Crisis: How Can Export Credit Agencies Help? Review of International Comparative Management, vol. 13(1), p. 167-180.

Dinh, T. Q., Hilmarsson, H. P. (2012c). How Can Private Companies Use the Financial Services and Risk Mitigation Instruments Offered by Export Credit Agencies in Emerging Markets? Proceedings. Project Development - Practice and Perspectives. First International Scientific Conference on Project Management in the Baltic Countries, p. $14-25$.

Dinh, T. Q., Hilmarsson, H. P. (2013, July 3-6). Export credit agencies, cross border trade, times of crisis, and increased value added in emerging economies industrial sectors. Conference article presented at the 55th Annual Meeting of the Academy of International Business.

Dinh, T. X. (2009). Dinh, X.T. (xuantung168@gmail.com) 13 July 2011, RE: Report on Investigation of Component, Productivity and Organization of Pig, Buffalo and Beef Production 2009. Email to Dinh T. Q. (quangtrung38@gmail.com). Vietnam.

FAO. (2005). Information of Fishery Sector - Vietnam. Retrieved September 4, 2013, from Food and Agriculture Organization. Website: http://www.fao.org/fi/oldsite/FCP/en/VNM/profile.htm

FAO. (2008a). FAOSAT. Exports - Commodities by Country - Vietnam. Retrieved September 2, 2013. Website: http://faostat.fao.org/site/342/default.aspx

FAO. (2008b). Poultry Production Systems in Vietnam. Retrieved September 4, 2013, from Food and Agriculture Organization. Website: http://www.fao.org/docrep/013/al693e/al693e00.pdf

FAO. (2008c). Countries by Commodity. Top Production - Indigenous Pigmeat - Vietnam - 2008. Retrieved September 4, 2013. Website: fao.org: http://faostat.fao.org/site/339/default.aspx

FAO. (2009a). FAOSTAT. Production of Poultry - Vietnam. Retrieved September 6, 2013, from Food and Agriculture Organization. Website: http://faostat.fao.org/site/569/DesktopDefault.aspx?PageID=569\#ancor

FAO. (2009b). FAOSTAT. Production of Pork - Vietnam. Retrieved September 6, 2013, from faostat.fao.org: http:// faostat.fao.org/site/569/DesktopDefault.aspx?PageID=569\#ancor

GAIN. (2008). Vietnam Retail Food Sector 2008. Global Agriculture Information Network. HCM City: USDA Foreign Agricultural Service - US Consulate. Retrieved from September 10, 2013. Website: http://www.fas.usda.gov/gainfiles/200811/146306458.pdf

GAIN. (2009). Exporter Guide Annual - Vietnam Exporter Guide 2009. Retrieved August 28, 2013, from Global Agricultural Information Network. Website: http://gain.fas.usda.gov/Recent\%20GAIN\%20Publications/EXPORTER\%20GUIDE\%20ANNUAL_Hanoi_Vietnam_10-15-2009.pdf

Royal Royal Embassy of Denmark. (2010). The Fisheries Sector in Vietnam: A Strategic Economic Analysis. Royal Embassy of Denmark in Vietnam - Fisheries Sector Programme Support (FSPS) II. Retrieved August 25, 2013. Website: $\mathrm{http}: /$ www.google.com.vn/url?sa=t\&rct=j\&q=\&esrc=s\&source=web\&cd=1\&ved=0CDAQFjAA\&url $=\mathrm{http} \%$ 3A\%2F\%2Fwww.ciem.org.vn\%2Fhome\%2Fen\%2Fupload\%2Finfo\%2Fattach\%2F13018993735150_FishReportUoCCIEM.pdf\&ei=BhBIUriaCq2aiQey04HoCA\&usg=AFQjCNG5I16uYEsp34TzSZWrDhO1fpqMkQ\&bvm=b v.53217764,d.aGc

Sacombank. (2010). Review of Vietnam's Fisheries Sector and Estimates - SBS Securities. Retrieved September 16, 2013, from Sai Gon Thuong Tin Bank. Website: http://www.sbsc.com.vn/portal/sbsfiles//others/e4bb49bd-a8bd4c48-809d-6b5b147341bf.pdf

Seafood Source. (2011, December 28). Seafood News Supply \& Trade. Retrieved September 12, 2013, from SeafoodSource.com. Website: http://www.seafoodsource.com/newsarticledetail.aspx?id=13481

Swiss Business Hub ASEAN. (2006). Market Report - Food Processing and Packaging Equipment Market in ASEAN - an Industry Overview. (S. C. Ltd, Producer) Retrieved August 26, 2013. Website: http://www.google. com.vn/url?sa=t\&rct=j\&q=\&esrc=s\&source=web\&cd=1\&cad=rja\&ved=0CCkQFjAA\&url=http $\% 3 \mathrm{~A} \% 2 \mathrm{~F} \% 2 \mathrm{Fs} 3$. 
amazonaws.com\%2Fzanran_storage\%2Fwww.sippo.ch\%2FContentPages\%2F47420351.pdf\&ei=FhNIUsPRO6m piAfJsYCYCw\&usg=AFQjCNFGn269iNWAIDAaC4kiv9_T2QD-5w\&bvm=bv.53217764,d.aGc

VASEP. (2009). Vietnam's Fisheries Exports 2009. Le, H. (lehang@vasep.com.vn) 14 July 2011, RE: Statistics of Vietnam's Fisheries Exports 2009. Email to Dinh T.Q. (quangtrung38@gmail.com). Vietnam.

VASEP. (2010). Vietnam's Fisheries Exports 2010. Le, H. (lehang@vasep.com.vn) 22 July 2011, RE: Statistics of Vietnam's Fisheries Exports 2010. Email to Dinh T. Q. (quangtrung38@gmail.com). Vietnam.

World Bank. (2009). Project Appraisal Document On A Proposed Credit In the Amount of SDR 42.1 Million (US\$ 65.26 Million Equivalent) to the Socialist Republic Of Vietnam For A Livestock Competitiveness and Food Safety Project. East Asia and Pacific Region: The World Bank. Retrieved August 28, 2013. Website: http://www-wds.worldbank. org/external/default/

WDSContentServer/WDSP/IB/2009/09/03/000333038_20090903025309/Rendered/PDF/501610PAD0P09011y10ID A1R20091024411.pdf

\section{MAISTO PRAMONE் VIETNAME: KUR SLYPI AUKŠTOS VERTÉS EKSPORTO POTENCIALAS?}

Trung Quang Dinh, Hilmar Pór Hilmarsson

Akureyri universitetas (Islandija)

Santrauka

Vietnamas yra kylanti rinkos šalis Pietryčiu Azijoje. Kaip ir daugelis šio regiono šalių, Vietnamas taiko eksportu grindžiamo augimo strategiją. Neseniai jis tapo vidutinių pajamų šalimi, tačiau siekia tapti didelių pajamų šalimi. Vietnamas yra stambus maisto prekių gamintojas ir eksportuotojas. Norint pasiekti aukštesni pajamų lygi, šaliai reikia didinti gaminamų produktų pridètinę vertę ir daugiau eksportuoti ị aukštesnio pragyvenimo lygio šalis. Ar Europos pažangių maisto gamybos sprendimų gamintojams realu realizuoti savo produkciją Vietname? Šiame straipsnyje analizuojamos ir vertinamos jūros gërybių bei gyvulių rinkos. Daroma išvada, kad yra realios galimybės pažangiu gamybos sprendimų tiekejjams parduoti savo produkciją tiek žuvininkystės, tiek gyvulininkystės sektoriuose. Didžiausias augimo potencialas artimiausiu laikotarpiu yra žuvininkystès sektoriuje, o vidutiniu ir ilguoju laikotarpiu - gyvulininkystės sektoriuje.

PAGRINDINIAI ŽODŽIAI: žemès ūkio produkcija ir eksportas, maisto pramone, žuvininkysté, gyvulininkystè, patekimas i rinka, Vietnamas.

JEL KODAI: M31, N7, Q1 